\title{
Spontaneous poisoning by Ricinus communis (Euphorbiaceae) in cattle ${ }^{1}$
}

\author{
Samuel S.C. Albuquerque ${ }^{2}$, Brena P. Rocha ${ }^{2}$, Raquel F. Albuquerque ${ }^{2}$, Juceli S. \\ Oliveira $^{3}$, Rosane M.T. Medeiros ${ }^{4}$, Franklin Riet-Correa ${ }^{4}$, Joaquim Evêncio-Neto ${ }^{5}$ \\ and Fábio S. Mendonça ${ }^{5 *}$
}

\begin{abstract}
Albuquerque S.S.C., Rocha B.P., Albuquerque R.F., Oliveira J.S., Medeiros R.M.T., Riet-Correa F., Evêncio-Neto J. \& Mendonça F.S. 2014. Spontaneous poisoning by Ricinus communis (Euphorbiaceae) in cattle. Pesquisa Veterinária Brasileira 34(9):827-831. Universidade Federal Rural de Pernambuco, Rua Dom Manoel de Medeiros s/n, Dois Irmãos, Recife, PE 52171-900, Brazil. E-mail: fabio.mendonca@pq.cnpq.br

The aim of this study is to report cases of spontaneous poisoning of cattle by Ricinus communis (castor beans) in Paraíba, a semiarid region of northeastern Brazil. The cases were observed in 2 herds on neighboring properties in 2013. Clinical signs developed within 6-24 h and consisted of weakness, tachycardia, dyspnea, profuse watery diarrhea, dehydration, depression, instability, cramps, permanent lateral recumbency and death within 48-72 h. Of the 60 cattle at risk, 19 were affected and 14 died. Five fully recovered after the course of 12 days. Three animals were necropsied. The main gross lesions were hemopericardium, hemothorax, pulmonary edema, petechial hemorrhages in the epicardium and endocardium, ecchymoses at the papillary muscles and suffusions on the intercostal muscles. Hemorrhages were also observed in the abdominal cavity, spleen and mucosa of the abomasum and small intestine. The rumen content was liquid with a large amount of castor bean seeds. There were circular, whitish and focally diffuse areas in the liver parenchyma. The main microscopic lesions consisted of multifocal coagulative myocardial necrosis with the presence of mononuclear cell infiltration and varying degrees of bleeding between cardiac muscle fibers. The abomasum and small intestine mucosae and submucosa had mild edema and mononuclear and polymorphonuclear inflammatory cell infiltration. The diagnosis of $R$. communis was based on the history of plant consumption, clinical signs, pathology of the disease and the presence of large amounts of castor bean seeds in the forestomachs.
\end{abstract}

INDEX TERMS: Poisonous plants, castor bean plant, Ricinus communis, Euphorbiaceae, plant poisoning, gastroenteritis, cattle.

RESUMO.- [Intoxicação espontânea por Ricinus communis (Euphorbiaceae) em bovinos.] 0 objetivo deste trabalho é relatar casos de intoxicação espontânea em bovinos por Ricinus communis (mamona) na Paraíba, região semi-árida do nordeste do Brasil. Os casos foram observados em dois rebanhos de propriedades vizinhas no ano de

\footnotetext{
${ }^{1}$ Received on July 2, 2014.

Accepted for publication on August 5, 2014.

${ }^{2}$ Programa de Pós-Graduação em Ciência Veterinária, Departamento de Medicina Veterinária, Universidade Federal Rural de Pernambuco (UFRPE), Rua Dom Manoel de Medeiros s/n, Dois Irmãos, Recife, PE 52171900, Brazil.

${ }^{3}$ Programa de Pós-Graduação em Ciência Animal Tropical, Departamen-
}

2013. Os primeiros sinais clínicos se desenvolveram dentro de 6-24 h e consistiam em fraqueza, taquicardia, dispnéia, diarréia aquosa profusa, desidratação, depressão, instabilidade, cólicas, decúbito lateral permanente e morte em 48-72h. Dos 60 bovinos sob risco, 19 foram afetados e 14 morreram. Cinco bovinos se recuperaram totalmente após

to de Morfologia e Fisiologia Animal (DMFA), UFRPE, Rua Dom Manoel de Medeiros s/n, Dois Irmãos, Recife, PE 52171-900.

${ }^{4}$ Hospital Veterinário, CSTR, Campus de Patos, Universidade Federal de Campina Grande (UFCG), Patos, PB 58700-000.

${ }^{5}$ Laboratório de Diagnóstico Animal, Departamento de Morfologia e Fisiologia Animal, UFRPE, Rua Dom Manoel de Medeiros s/n, Dois Irmãos, Recife, PE 52171-900. *Corresponding author: fabio.mendonca@pq.cnpq.br 
um período de 12 dias. Três bovinos foram necropsiados. As principais lesões macroscópicas foram hemopericárdio, hemotórax, edema pulmonar, petéquias no epicárdio e endocárdio, equimoses nos músculos papilares e sufusões nos os músculos intercostais. Hemorragias também foram observadas na cavidade abdominal, baço e na mucosa do abomaso e intestino delgado. 0 conteúdo ruminal estava líquido, e continha grande quantidade de sementes de $R$. communis. No parênquima hepático havia áreas circulares, esbranquiçadas e distribuídas focalmente. As principais lesões microscópicas consistiam em necrose miocárdica coagulativa multifocal com a presença de infiltrado de células mononucleares e graus variados de hemorragias entre as fibras musculares cardíacas. 0 abomaso e a mucosa e submucosa do intestino delgado apresentavam edema discreto e infiltrado de células inflamatórias mononucleares e polimorfonucleares. 0 diagnóstico da intoxciação por $R$. communis foi baseado na história de consumo de planta, sinais clínicos, patologia da doença e pela presença de grandes quantidades de sementes de $R$. communis no sistema digestório dos bovinos.

TERMOS DE INDEXAÇÃO: Plantas tóxicas, mamona, Ricinus communis, Euphorbiaceae, intoxicação por plantas, gastroenterite, bovinos.

\section{INTRODUCTION}

Ricinus communis L. (Euphorbiaceae), commonly called castor bean, Palma(e) Christi or wonder tree, is an upright, bushy African plant that is found on every continent. The Ricinus genus is considered monotypic; and the recognized subspecies are $R$. sinensis, $R$. zanzibarensis, $R$. persicus and $R$. africanus, which include 25 botanical varieties (Anjos \& Silva et al. 2014).

In some countries, the cultivation of $R$. communis has increased because its seeds are used for biofuel/biodiesel production. India, China and Brazil produce approximately $1 \mathrm{Mt}$ of castor bean oil annually for biodiesel production (Mutlu \& Meier 2010).

Despite several reports of accidental poisoning in humans by unprocessed seeds of $R$. communis (De Paepe et al. 2005, Nishiyama et al. 2005, Lucas et al. 2006, Al-Tamimi et al. 2008) cases of poisoning in animals have occurred after the intake of processed seeds (Worbs et al. 2011). In Brazil, the data reported to date were mainly from experimental studies in cattle, sheep and rabbits (Armién et al. 1996, Brito \& Tokarnia 1997, Tokarnia \& Döbereiner 1997) and spontaneous cases of poisoning in cattle have not been described.

This study aims to describe the epidemiology and clinical and pathological profiles of spontaneous outbreaks of $R$. communis poisoning in cattle in the semiarid region of Paraíba, northeastern Brazil.

\section{MATERIALS AND METHODS}

Epidemiological and clinical data of Ricinus communis poisoning in cattle were obtained from the owners and veterinarians during technical visits in the municipality of Salgado de São Félix, Paraíba, in northeastern Brazil.
Three crossbred, female dairy cattle, averaging 5 years of age, presented with serious diarrhea and were necropsied after spontaneous death. The brain, spinal cord and fragments of liver, kidney, heart, lung, spleen, rumen, reticulum, omasum, abomasum and intestines were collected, fixed in 10\% formalin, processed routinely, stained with hematoxylin and eosin (HE) and examined microscopically.

Seven cattle from the same herd became sick, were removed from the area infested by $R$. communis and were kept in a corral for 21 days for clinical evaluation. The cattle were evaluated twice weekly as described by Stöber (1993) and Dirksen (1993). Their general condition, behavior, attitude, appetite, color of mucous membranes, rectal temperature, heart and respiratory rates, form of abdomen, and rumen/reticulum motility were recorded. Additionally, rumen fluid and fecal samples were collected.

Examination of rumen fluid was performed according to Dirksen (1993) and Miranda Neto et al. (2005). The pH of the rumen fluid samples was measured at the time of sampling using $\mathrm{pH}$ indicator strips. The color, odor, appearance, sedimentation-flotation, reduction of methylene blue and protozoa activity were analyzed. The density, motility, live-dead ratio and predominance of protozoa were evaluated by direct microscopy (Dehority 1993).

To perform biochemical and blood count tests, samples of blood were collected using a vacuum system through puncture of the jugular vein. Blood samples were collected once a week for a total of 3 collections. Each sample was stored in $210 \mathrm{~mL}$ tubes, 1 with the anticoagulant sodium ethylenediaminetetraacetate (EDTA) in a $10 \%$ aqueous solution and the other without. The serum was separated by centrifugation at $2.500 \mathrm{rpm}$ for $10 \mathrm{~min}-$ utes and maintained at $-20^{\circ} \mathrm{C}$ until analysis. The biochemical tests were performed using a kinetic process with commercial enzyme kits for aspartate aminotransferase (AST), creatine phosphokinase (CPK), gamma glutamyl transferase (GGT), urea, creatinine and bilirubins (Lopes et al. 2007).

\section{Clinical history}

Two herds of crossbred dairy cattle, with about 60 head each, were raised semi-extensively in a native caatinga (savanna) on neighboring properties. Between March and April 2013, 14 cattle were found dead after being taken to graze along the bank of the Paraíba do Norte river, in the microregion of Itabaiana, municipality of Salgado de São Félix ( $07^{\circ} 21^{\prime} 25^{\prime \prime} \mathrm{S} / 35^{\circ} 26^{\prime} 26^{\prime \prime} \mathrm{W}$ ), Paraíba, northeastern Brazil. The rainfall in the city was $748.7 \mathrm{~mm}$ in 2013, with only $52 \mathrm{~mm}$ of rainfall in the 6 months preceding the poisoning. Due to the prolonged drought, animals were grazed along the riverbank where there were still areas of green vegetation.

Scarcity of pasture and invasion of Ricinus communis were observed. The leaves and the fruits of the plants had been heavily consumed by cattle, and some cattle took down the scrubs to consume the leaves and fruits (Fig.1A and $1 \mathrm{~B})$.

\section{Clinical and pathological picture}

Clinical signs developed within 6-24 h after the cattle were moved to the area invaded by the plant. The examined cattle were markedly thin and dehydrated, with brittle and bristly hair and foul-smelling, blackish-brown feces on the perianal region and parts of the hind limbs. These signs were consistent among all affected cattle. Five cattle sho- 

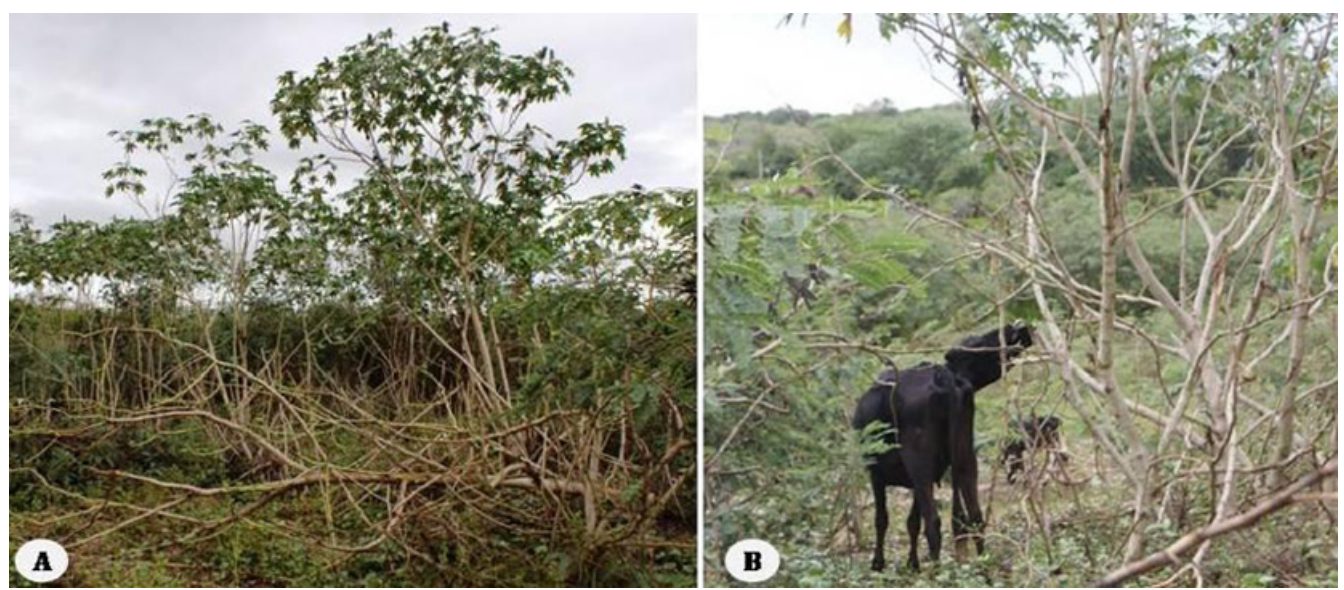

Fig.1. (A) Ricinus communis, fallen tree in grazing area with evidence of consumption by cattle. (B) Cattle eating the leaves and fruits of $R$. communis.

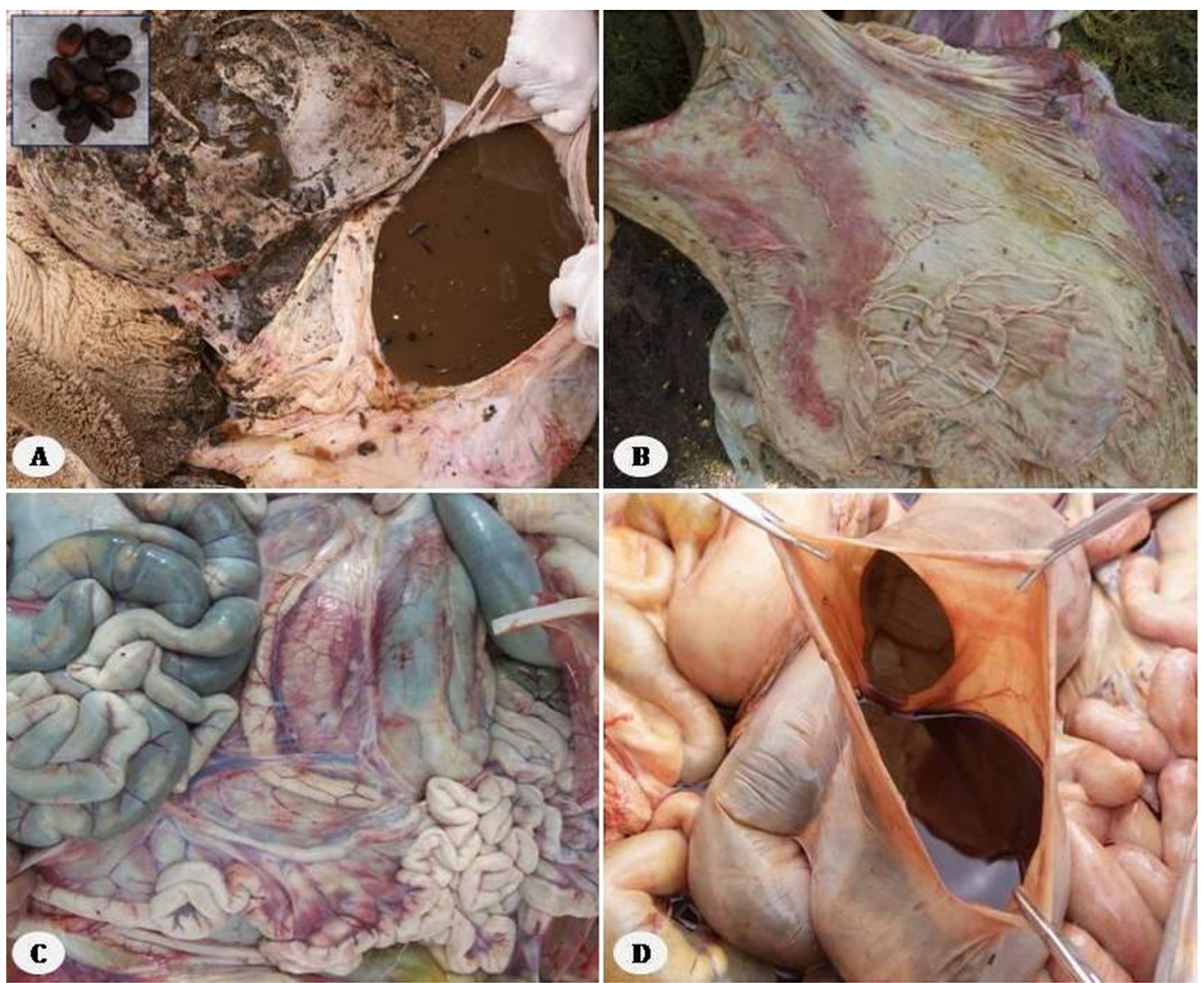

Fig.2. (A) Content of abomasum intensely liquid, brownish-blackish. Inset: $R$. communis seeds taken from the rumen and omasum. (B) Hyperemia, petechial hemorrhages and edema of abomasum's mucosa folds. (C) Hemorrhages in the mesentery, intestinal serosa. (D) Hemorrhagic content in the large intestine.

wed mild clinical signs and recovered fully after a course of 12 days. The animals that died of poisoning also exhibited apathy, tearing, drooling, congestion of episcleral vessels, severe dehydration, abdominal pain with percussion test, ruminal stasis, watery and blood feces, and weakness with shaky, unsteady gait. Rales and evidence of pulmonary consolidation were noted on auscultation. These signs progressed to severe depression, sternal recumbency, lateral recumbency and death within 48-72 hours.
The ruminal fluid of cattle that recovered from the poisoning showed no changes in color or appearance. One calf had ruminal acidosis ( $\mathrm{pH}$ 5.5) and decreased reduction of methylene blue activity, density and motility of rumen microfauna. Hematological abnormalities were mild and consisted of normochromic normocytic anemia, slightly increased values of total plasma protein and leukocytosis with neutrophilia. No change in plasma fibrinogen or serum levels of AST, CPK, GGT, urea, creatinine or bilirubin were identified. 
Hemopericardium, hemothorax, pulmonary edema, petechial hemorrhages in the epicardium and endocardium, bruises on papillary muscles and suffusion in intercostal muscles were observed at necropsy. Hemorrhages were also observed in the abdominal cavity, intercostal muscles, spleen and kidneys. The contents of the rumen, reticulum and omasum were dry and contained seeds of the plant. The content of the abomasum was extremely fluid, and its mucosa was red with swollen folds (Fig.2A and 2B). Hemorrhages were present in the mesentery and serosa of the abomasum and small and large intestines (Fig.2C). The intestinal loops were distended and contained a significant amount of blood (Fig.2D). The mesenteric lymph nodes were enlarged and edematous. The liver was swollen and congested with a lobular pattern, and the gallbladder was distended.

Histologically, the myocardium showed multifocal coagulative necrosis with mononuclear infiltration of cells and different degrees of hemorrhage between cardiac muscle fibers (Fig.3). The interlobular septa of the lungs were dis-

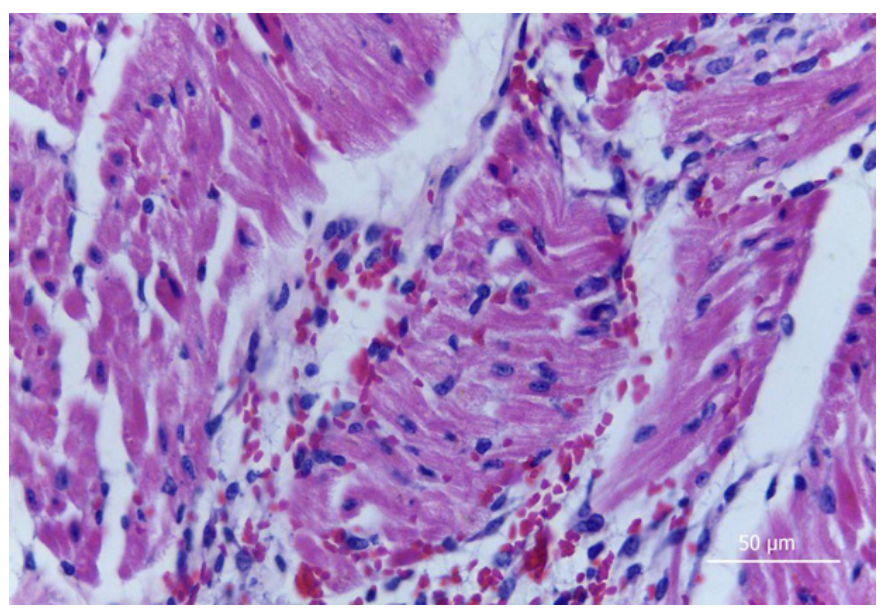

Fig.3. Hemorrhages and coagulation necrosis of myocardium, increased cytoplasmic eosinophilia, pyknotic nuclei, cariorrexia, karyolysis and loss of striations in cardiomyocytes. HE, Bar $=50 \mu \mathrm{m}$.

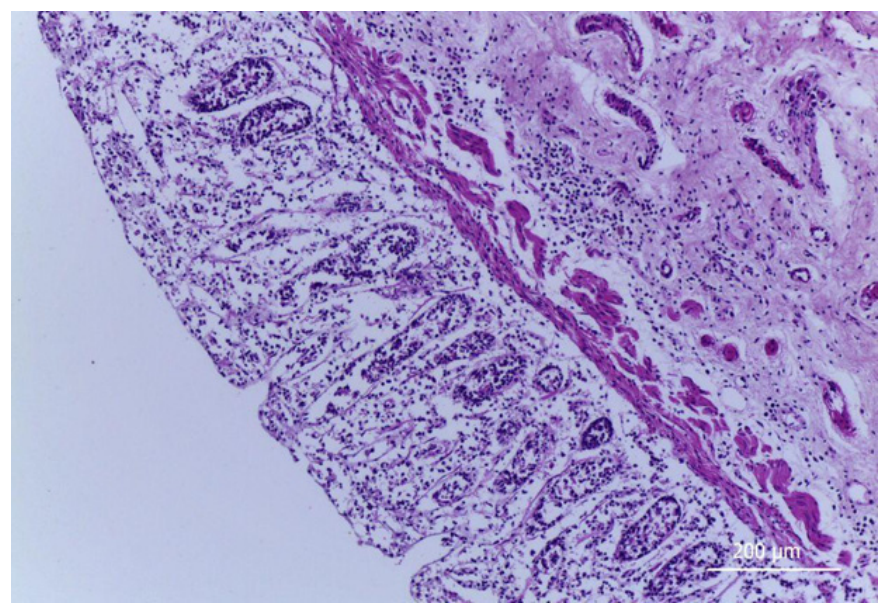

Fig.4. Necrosis of abomasum's mucosa with infiltrate of mononuclear and polymorphonuclear inflammatory cells and submucosa edema. HE, Bar $=50 \mu \mathrm{m}$. tended by edema, and the airway lumen contained hyaline material, desquamated pneumocytes, macrophages and polymorphonuclear cells. The abomasums and small intestine mucosa had mild inflammatory infiltration of mononuclear and polymorphonuclear cells and submucosal edema (Fig.4). The liver showed slight individual necrosis of hepatocytes, edema of the spaces of Disse and proliferation of biliary ducts cells. The splenic lymph nodes showed hypocellularity, with pale germinal centers, and contained numerous lymphocytes with pyknotic nuclei.

\section{DISCUSSION AND CONCLUSION}

The diagnosis of spontaneous poisoning by Ricinus communis was based on the history of plant consumption, epidemiological data, clinical signs, necropsy and histological findings. In the described outbreaks, cattle ingested both the leaves and seeds of $R$. communis. This information was confirmed by field observations. The cattle were observed ingesting the aerial parts of the plant, seeds were present in the digestive systems of the necropsied cattle, and fallen trees showed signs of consumption. These findings are important for the diagnosis of poisoning because necropsy and histological lesions are nonspecific (Worbs et al. 2011).

The clinicopathological picture of affected cattle showed mainly gastroenteric changes due to the spontaneous consumption of $R$. communis seeds. This result most likely occurred because the ricin contained in the seeds is more toxic than the ricinine contained in the leaves and pericarp of the plant. In cattle, the lethal dose of ground seeds is $2 \mathrm{~g} /$ $\mathrm{kg}$ for adults and $0.5 \mathrm{~g} / \mathrm{kg}$ for calves whereas the lethal dose of leaves for adult cattle is $20 \mathrm{~g} / \mathrm{kg}$ (Tokarnia et al. 1975, Döbereiner et al. 1981, Tokarnia et al. 2012).

The mortality rate of the cases reported here is high (23.3\%), even when compared to cases of accidental poisoning in several other species (Vigener 1974, Fernandes et al. 2002, Aslani et al. 2007). In ruminants, increased mastication can increase morbidity and mortality. Most seeds can pass through the digestive system intact, but mastication and rumination can significantly enhance the release of ricin from plant seeds (Albretson et al. 2000, Johnson et al. 2005). Additionally, the lethal dose of seeds can vary by the age and sensitivity of the animal, even among animals of the same species (Worbs et al. 2011, Tokarnia et al. 2012).

The various seeds of $R$. communis cultivars contain different levels of ricin D, ricin E and Ricinus communis agglutinin (RCA). Ricin is the main alkaloid involved in the pathogenesis of poisoning because this toxin is 100-2000 times more toxic than agglutinin (Lin et al. 1980, Lord et al. 1994, Brandt et al. 2001). These toxins bind to their receptors on cell membranes, are internalized and are transported by endocytosis to the endoplasmic reticulum where they cause protein inactivation and cell death. In the cardiovascular system, ricin causes a severe reduction in the intracellular calcium flux (Ma et al. 1995). These changes are largely responsible for the bleeding observed in the various tissues of cattle that died of intoxication (Lord et al. 1994, Christiansen et al. 1991, Spooner \& Watson 2010). 
$R$. communis is often cited by farmers as the cause of death, especially of cattle, in epidemiological surveys conducted by our team in semiarid regions of Pernambuco and Paraíba. In cattle, spontaneous poisoning is always associated with intense hunger and, historically, poisonings have occurred in years of prolonged drought. There is no specific treatment for poisoning by $R$. communis, but therapy should be based on the clinical signs of the animals. In years of severe drought in the semiarid northeastern region, prophylaxis consists of eradication of the plant or keeping the cattle away from areas where there is a severe propagation of $R$. communis (Albretson et al. 2000, Albretson 2003, Doan 2004, Tokarnia et al. 2012).

Acknowledgements.- This study was supported by National Institute for Science and Technology for the Control of Plant Poisonings, National Council of Scientific and Technological Development (CNPq Grant: 573534/2008-0).

\section{REFERENCES}

Albretson J.C., Gwaltney-Brant S.M. \& Khan S.A. 2000. Evaluation of castor bean toxicosis in dogs: 98 cases. J. Am. Anim. Hosp. Assoc. 36:229-233.

Albretson J.C. 2003. Lectins, p.406-408. In: Plumlee K.H. (Ed.), Clinical Veterinary Toxicology. Mosby, St Louis.

Al-Tamimi F.A. \& Hegazi A.E. 2008. A case of castor bean poisoning. Sultan Qaboos Univ. Med. J. 8:83-87.

Anjos e Silva S.D., Casagrande Júnior J.G. \& Aires R.F. 2014. Sistema de produção da mamoma. Disponível em <http://sistemasdeproducao.cnptia. embrapa.br/FontesHTML/Mamona/SistemaProducaoMamona/index. htm> Acesso em 24 jan. 2014.

Armién A.G., D’Angelis F.H. \& Tokarnia C.H. 1996. Intoxicação experimental pelas sementes de Ricinus communis (Euphorbiaceae) em ovinos. Pesq. Vet. Bras. 16(4):99-106.

Aslani M.R., Maleki M., Mohri M., Sharifi K., Najjar-Nezhad V. \& Afshari E. 2007. Castor bean (Ricinus communis) toxicosis in a sheep flock. Toxicon 49:400-406.

Brandt N.N., Chikishev A.Y., Sotnikov A.I., Savochkina Y.A., Agapov I.I., Tonevitskii A.G. \& Kirpichnikov M.P. 2001. Conformational difference between ricin and ricin agglutinin in solution and crystal. Dokl. Biochem. Biophys. 376:26-28.

Brito M.F. \& Tokarnia C.H. 1997. Intoxicação experimental pelas sementes trituradas de Ricinus communis (Euphorbiaceae) em coelhos. Pesq. Vet. Bras. 17(1):1-7.

Christiansen V.J., Hsu C.H., Kosanke S.D. \& Robinson C.P. 1991. Histological and laboratory value abnormalities following ricin administration in rabbits. Pharmacol. 33:210.

De Paepe P., Gijsenbergh F., Martens F., Piette M. \& Buylaert W. 2005. Two fatal cases following ricin injection. Brit. J. Clin. Pharmacol. 59:125-126.

Dirksen G. 1993. Sistema digestivo, p.166-228. In: Dirksen G., Gründer
H.D. \& Stöber M. (Eds), Rosenberger Exame Clínico dos Bovinos. 3aㅡ ed. Guanabara Koogan, Rio de Janeiro.

Doan L.G. 2004. Ricin: mechanism of toxicity, clinical manifestations and vaccine development. J. Toxicol. 24:201-209.

Döbereiner J., Tokarnia C.H. \& Canella C.F.C. 1981. Experimental poisoning of cattie by the pericarp of the fruit of Ricinus communis. Pesq. Vet. Bras. 1(3):9597.

Fernandes W.R., Baccarin R.Y.A. \& Michima L.E.S. 2002. Equine poisoning by Ricinus communis: case report. Revta Bras. Saúde Prod. An. 3:26-31.

Lin T.T.S. \& Li S.S.L. 1980. Purification and physicochemical properties of ricins and agglutinins from Ricinus communis. Eur. J. Biochem. 105:453459.

Lopes S.T.A., Biondo A.P.S. \& Santos A.P. 2007. Manual de Patologia Clínica Veterinária. 3a ed. Departamento de Clínica de Pequenos Animais, UFSM, Santa Maria, p.5-45.

Lord J.M., Roberts L.M. \& Robertus J.D. 1994. Ricin: structure, mode of action, and some current applications. FASEB J. 8:201-208.

Lucas G.N. 2006. Plant poisoning in Sri Lankan children: a hospital based prospective study. Sri Lanka J. Child Health 35:111-124.

Ma L., Hsu C.H., Fugate R., Paterson E., Thadani U. \& Robinson C.P. 1995. Ricin disturbs calcium homeostasis in the rabbit heart. J. Biochem. Toxicol. 10:323-328.

Miranda Neto E.G., Afonso J.A.B., Mendonça C.L. \& Almeida M.Z.P.R.B. 2005. Avaliação do comportamento clínico e das características do suco ruminal em caprinos com acidose lática induzida experimentalmente. Pesq. Vet. Bras, 25(2):73-78.

Mutlu H. \& Meier M.A.R. 2010. Castor oil as a renewable resource for the chemical industry. Eur. J. Lipid Sci. Technol. 112:10-30.

Nishiyama T., Oka H., Miyoshi M., Aibiki M., Maekawa S. \& Shirakawa Y. 2005. Case of accidental ingestion of caster beans: Acute intoxication by ricin. Chudoku Kenkyu. 18:149-150.

Spooner R.A. \& Watson P. 2010. Drug targeting: learning from toxin entry and trafficking in mammalian cells. Curr. Opin. Drug Discov. Devel. 13:86-95.

Stöber M. 1976. Identificação, anamnese, regras básicas da técnica de exame clínico geral, p.44-80. In: Dirksen G., Gründer H.D. \& Stöber M. (Eds), Exame Clínico dos Bovinos. 3aㅡ ed. Guanabara Koogan, Rio de Janeiro.

Tokarnia C.H., Döbereiner J. \& Canella C.F.C. 1975. Intoxicação experimental em bovinos pelas folhas de Ricinus communis. Pesq. Agropec. Bras., Sér. Vet. 10:1-7.

Tokarnia C.H. \& Döbereiner J. 1997. Imunidade cruzada pelas sementes de Abrus precatorius e Ricinus communis em bovinos. Pesq. Vet. Bras. 17(1):25-35.

Tokarnia C.H., Brito M.F., Barbosa J.D., Peixoto P.V. \& Döbereiner J. 2012. Plantas Tóxicas do Brasil para Animais de Produção. $2^{\text {a }}$ ed. Editora Helianthus, Rio de Janeiro.

Vigener A. 1874. Untersuchung eines verfälschten Leinmehls. 1874. Arch. Pharm. 204:495-506.

Worbs S., Köhler K., Pauly D., Avondet M., Schaer M., Dorner M.B. \& Dorner B.G. 2011. Ricinus communis Intoxications in Human and Veterinary Medicine: a summary of real cases. Toxins 3:1332-1372. 